\title{
Anti-oxidant and anti-inflammatory activities of the various kinds of herbal tea
}

\author{
Jin Wook Lee ${ }^{1 \#}$, Hyun Ji Eo ${ }^{1}$, Gwang Hun Park ${ }^{1}$, Hun Min Song ${ }^{1}$, So Hee Woo ${ }^{1}$, \\ Mi Kyoung Kim', Jung Hye Eom ${ }^{2}$, Man Hyo Lee ${ }^{3}$, Jeong Rak Lee ${ }^{3}$, \\ Jin Suk Koo ${ }^{1,2}$, Jin Boo Jeong ${ }^{1,2^{*}}$ \\ 1 : Department of Bioresource Sciences, Andong National University, Andong, 760749, Korea \\ 2 : Department of Medicinal Plant Resources, Andong National University, Andong, 760749, Korea \\ 3 : Gyeongbuk Institute for Bio-industry, Andong, 760380, Korea
}

\begin{abstract}
Objectives : Reactive oxygen species (ROS) are involved in a wide spectrum of diseases including chronic inflammation and cancer. In this study, we investigated the antioxidant activities and anti-inflammatory effects of the extracts from the herbal teas such as Lonicera japonica Thunberg ( $L$. japonica), Chrysanthemum morifolium Ramat (C. morifolium), Mentha arvensis L. (M. arvensis), and P.rhizoma.

Methods : Anti-oxidant activity was evaluated using DPPH radical scavenging assay and $\mathrm{Fe}^{2+}$ chelating assay. And DNA cleavage assay was performed to evaluate an anti-oxidative effect. Anti-inflammatory effect was performed using NO generation assay and western blot in LPS-stimulated RAW264.7 cell line.

Results : L. japonica scavenged DPPH radical by $9.8 \%$ at $12.5 \mu \mathrm{g} / \mathrm{ml}, 24.8 \%$ at $25 \mu \mathrm{g} / \mathrm{ml}, 34.3 \%$ at $50 \mu \mathrm{g} / \mathrm{ml}$, $61.1 \%$ at $100 \mu \mathrm{g} / \mathrm{ml}$ and $75.8 \%$ at $200 \mu \mathrm{g} / \mathrm{ml}$, respectively. In addition, C. morifolium and $M$. arvensis removed DPPH radical by $15.6 \%$ and $10.4 \%$ at $12.5 \mu \mathrm{g} / \mathrm{ml}, 34.8 \%$ and $22.8 \%$ at $25 \mu \mathrm{g} / \mathrm{ml}, 66.9 \%$ and $43.3 \%$ at $50 \mu \mathrm{g} / \mathrm{ml}$, $87.4 \%$ and $69.1 \%$ at $100 \mu \mathrm{g} / \mathrm{ml}$, and $92.1 \%$ and $73.2 \%$ at $200 \mu \mathrm{g} / \mathrm{ml}$, respectively. However, P. rhizoma did not affect on DPPH radical scavenging. The $\mathrm{Fe}^{2+}$ chelating activity was highest in $L$. japonica, but lowest in P. rhizoma among the herbal teas. In addition, the extracts from $L$. japonica, $C$. morifolium and $M$. arvensis inhibited oxidative DNA damage via its anti-oxidant activity. In anti-inflammatory effect, the extracts from $C$. morifolium inhibited $\mathrm{NO}$ production. In addition, it suppressed the $\mathrm{NF}-\kappa \mathrm{B}$ signaling pathway in LPS-stimulated RAW 264.7 cells.

Conclusions : Together, this study indicates that $L$. japonica, $M$. arvensis and $C$. morifolium possess the protective effect against the oxidative DNA damage. Furthermore, $C$. morifolium exerts an anti-inflammatory effect.
\end{abstract}

Key words : Herbal teas; Anti-oxidant; Oxidative damage; Anti-inflammation

\section{Introduction}

Reactive oxygen species (ROS) produced by cellular aerobic respiration have been regarded as a inducer of oxidative stress including damage of cell matrices such as lipids, proteins and DNA, which is associated with human diseases such as cancer and chronic inflammation ${ }^{1-3)}$. Thus, antioxidant activity can be defined as a suppression of oxidative damage of organic molecule including lipids, proteins, DNA and other molecules $^{4)}$. Antioxidants can be divided to two types; primary antioxidants directly remove the generated ROS and second antioxidants indirectly inhibits the ROS generation by Fenton's reaction. In generally, herbal teas have been reported to have these two type capacities $^{5)}$.

\footnotetext{
*Corresponding author : Jin Boo Jeong, Department of Medicinal Plant Resources, Andong National University, Andong, Korea, $760-749$. · Tel : +82-54-820-7757 · Fax : +82-54-820-6252 · E-mail : jjb0403@anu.ac.kr

\#First author : Jin Wook Lee, Department of Medicinal Plant Resources, Andong National University, Andong, Korea, 760-749.

· Tel : +82-54-820-7753 · E-mail : ghopur2@ naver.com

·접수 : 2014년 2월 21일 · 수정 : 2014년 3월 12일 · 채택 : 2014년 3월 13일
} 
In addition, ROS have been regarded as a mediator of chronic inflammation by activating proinflammatory cytokines, which has been regarded as a major mechanism for inflammation injury ${ }^{6)}$. Especially, ROS stimulates nitric oxide (NO), one of the inflammation mediators by which inflammatory processes can be provoked or sustained. Thus, free radicals are important mediators that provoke or sustain inflammatory processes and, consequently, their neutralization by antioxidants and radical scavengers can attenuate inflammation. Therefore, antioxidants can attenuate inflammation ${ }^{7)}$.

Teas have been regarded as the most widely consumed beverages worldwide ${ }^{8)}$. Among teas, herbal teas using the leaves, flowers, seeds, fruits, stems or roots of plant species have been consumed for health care and disease prevention ${ }^{9,10)}$ because these contain various active phytochemicals with pharmacological properties such as allergies, insomnia, headaches, anxiety, intestinal disorders, depression, and high blood pressure $^{11)}$. There is growing evidence that herbal teas have several biological effects including anti-cancer, anti-atherogenic, anti-oxidant and anti-microbial activities ${ }^{12)}$. In this study, we evaluated the anti-oxidant and anti-inflammatory capacities of aqueous extracts of Lonicera japonica Thunberg (L. japonica), Chrysanthemum morifolium Ramat (C. morifolium), Mentha arvensis L. ( $M$. arvensis), and $\mathrm{P}$. rhizomaused as a herbal tea.

\section{Materials and Methods}

\section{Chemicals}

1,1diphenyl-2-picrylhydrazyl

(DPPH) and lipopolysaccharide (LPS) were purchased from Sigma Aldrich Co. (St. Louis, USA), $\varphi \mathrm{X}-174$ RF I plasmid DNA was purchased from New England BioLabs (County Rood Ipswich, MA, USA). Antibodies against $\mathrm{I} \kappa \mathrm{B}-\alpha$, p65 and $\beta$-actin were purchased from Cell Signaling (Bervely, MA, USA). Cell culture media, Dulbecco's Modified Eagle medium (DMEM)/F-12 1:1 Modified medium (DMEM/F-12) was purchased from Lonza (Walkersville, MD, USA), pNF $\kappa$ B-Luc cis-Reporter plasmid was purchased from Agilent Technologies (Santa Clara, CA, USA).

\section{Sample preparation}

Herbal teas, L. japonica, C.morifolium, M. arvensis and P. rhizoma was kindly provided by Bonghwa Alpine Medicinal Plant Expriment Station, Korea. One hundred gram of the herbal teas was extracted with $300 \mathrm{ml}$ of distilled water in $100{ }^{\circ} \mathrm{C}$ for $90 \mathrm{~min}$. After
$90 \mathrm{~min}$, the extracts were filtered and freeze-dried. The freeze-dried extracts were kept at $-80{ }^{\circ} \mathrm{C}$ until use.

\section{Cell culture and treatmentf}

Mouse macrophage cell line, RAW264.7 cell was purchased Korean Cell Line Bank (Seoul, Korea) and grown in DMEM/F-12 supplemented with $10 \%$ fetal bovine serum (FBS), $100 \mathrm{U} / \mathrm{ml}$ penicillin and $100 \mu \mathrm{g} / \mathrm{ml}$ streptomycin. The cells were maintained at $37{ }^{\circ} \mathrm{C}$ under a humidified atmosphere of $5 \% \mathrm{CO}_{2}$. Aqueous extracts from the herbal tea were dissolved in $1 \times$ phosphate-buffered saline (PBS) and treated to cells. $1 \times$ PBS was used as a vehicle.

\section{DPPH radical scavenging assay}

DPPH radical scavenging assay was carried out according to the literature ${ }^{13)}$. Briefly, $760 \mu \mathrm{l}$ DPPH ethanol solution $(300 \mu \mathrm{M})$ solution and $40 \mu \mathrm{l}$ of the extracts were mixed and then incubated at $37{ }^{\circ} \mathrm{C}$ for $30 \mathrm{~min}$. After $30 \mathrm{~min}$, the absorbance was measured at $515 \mathrm{~nm}$

\section{5. $\mathrm{Fe}^{2+}$ chelating assay}

$\mathrm{Fe}^{2+}$ assay was performed according the literature ${ }^{13)}$. chelating The reaction mixture $(800 \mu \mathrm{l})$ contained 15 $\mu \mathrm{l}$ of $\mathrm{FeCl}_{2}(2 \mathrm{mM}), 150 \mu \mathrm{l}$ of varying concentrations of the extracts and $605 \mu \mathrm{l}$ distilled water. The mixture was shaken vigorously and left at room temperature for $30 \mathrm{~min}$. After $30 \mathrm{~min}, 30 \mu \mathrm{l}$ of ferrozine $(5 \mathrm{mM}$ in methanol) was added and mixed. The absorbance of the $\mathrm{Fe}^{2+}$-ferrozine complex was measured at $562 \mathrm{~nm}$.

\section{DNA cleavage assay}

Conversion of the supercoiled form of plasmid DNA to the open-circular and further linear forms has been used as an index of DNA damage ${ }^{14)}$. The reaction mixtures $(25 \mu \mathrm{l})$ containing $5 \mu \mathrm{l}$ of $\varphi \mathrm{X}-174 \quad \mathrm{RF} \quad \mathrm{I}$ plasmid DNA, $10 \mu \mathrm{l}$ of varying concentrations of the extracts and $5 \mu \mathrm{l}$ of $1 \mathrm{mM} \mathrm{FeSO}_{4}$ were incubated at $37{ }^{\circ} \mathrm{C}$ for $30 \mathrm{~min}$. After $30 \mathrm{~min}, 5 \mathrm{\mu l}$ of a solution containing 50\% glycerol (v/v), $40 \mathrm{mM}$ EDTA and $0.05 \%$ bromophenol blue was added to stop the reaction and the reaction mixtures were electrophoresed on 1\% agarose gel, and the DNA in the gel was visualized and photographed under ultraviolet light after ethidium bromide staining. 


\section{Nitric oxide generation}

RAW264.7 cells were plated in 12-well plate for overnight. Cells were pre-treated with the extracts from the herbal teas at the indicated concentrations for $2 \mathrm{~h}$ and then co-treat with LPS $(1 \mu \mathrm{g} / \mathrm{ml})$ for the additional $18 \mathrm{~h}$. After $18 \mathrm{~h}, 200 \mu \mathrm{l}$ of the media was mixed with equal amount of Griess reagent (1\% sulfanilamide and $0.1 \% \mathrm{~N}-1-$ (naphthyl) ethylenediamine-diHCl in $\left.2.5 \% \quad \mathrm{H}_{3} \mathrm{PO}_{4}\right)$. The mixture was incubated for the additional $5 \mathrm{~min}$ at the room temperature and the absorbance was measured at $540 \mathrm{~nm}$.

\section{Isolation and cytosol and nuclear fraction}

Nuclear and cytosolic fractions were prepared following the manufacturer's protocols of nuclear extract kit (Active Motif, Carlsbad, CA, USA). Briefly, RAW264.7 cells were washed with ice-cold PBS containing phosphatase inhibitors, harvested with 1xhypotonic buffer and then incubated at $4{ }^{\circ} \mathrm{C}$ for $15 \mathrm{~min}$. After 15 min, the cells were added with detergent and then centrifuged at $15,000 \mathrm{rpm}$ for $1 \mathrm{~min}$. The supernatants were collected as cytoplasmic fraction. Nuclear fractions were collected by suspending nuclear pellet with nuclear lysis buffer and centrifugation at 15,000 rpm for $10 \mathrm{~min}$.

\section{SDS-PAGE and Western blot}

Cells were washed with $1 \times$ phosphate-buffered saline (PBS), and lysed in radioimmunoprecipitation assay (RIPA) buffer (Boston Bio Products, Ashland, MA, USA) supplemented with protease inhibitor cocktail (Sigma Aldrich) and phosphatase inhibitor cocktail (Sigma Aldrich), and centrifuged at $15,000 \times \mathrm{g}$ for $10 \mathrm{~min}$ at $4^{\circ} \mathrm{C}$. Protein concentration was determined by the bicinchoninic acid (BCA) protein assay (Pierce, Rockford, IL, USA). The proteins were separated on SDS-PAGE and transferred to PVDF membrane (Bio-Rad Laboratories, Inc., Hercules, CA, USA). The membranes were blocked for non-specific binding with 5\% nonfat dry milk in Tris-buffered saline containing 0.05\% Tween 20 (TBS-T) for $1 \mathrm{~h}$ at room temperature and then incubated with specific primary antibodies in 5\% nonfat dry milk at $4^{\circ} \mathrm{C}$ overnight. After three washes with TBS-T, the blots were incubated with horse radish peroxidase (HRP)-conjugated immunoglobulin G (IgG) for 1 $\mathrm{h}$ at room temperature and chemiluminescence was detected with ECL Western blotting substrate (Amersham Biosciences) and visualized in Polaroid film.

\section{Transient transfection}

Transient transfection was performed using PolyJet DNA transfection reagent (SignaGen Laboratories, Ijamsville, MD, USA) according to the manufacturer's instruction. Briefly, RAW264.7 cells were seeded in 12-well plates and incubated overnight. Then, plasmid mixtures containing $0.5 \mu \mathrm{g}$ of $\mathrm{pNF}-\kappa \mathrm{B}-\mathrm{Luc}$ plasmid and 0.05 $\mu \mathrm{g}$ of $\mathrm{pRL}-$ null vector were transfected for $24 \mathrm{~h}$. After transfection, cells were pre-treated with the extracts from the herbal teas for $2 \mathrm{~h}$ and then co-treated with LPS for an additional $15 \mathrm{~h}$. The cells were harvested in 1 x luciferase lysis buffer, and luciferase activity was measured and normalized to the pRL-null luciferase activity using a dual-luciferase assay kit (Promega, Madison, WI, USA).

\section{Statistical analysis}

Statistical analysis was performed with the Students unpaired t-test, with statistical significance set at *, $P<0.05$

\section{Results}

\section{Antioxidant activities of herbal teas}

Antioxidant activities of herbal teas were evaluated using DPPH radical scavenging assay and $\mathrm{Fe}^{2+}$ chelating assay. Scavenging of DPPH radicals has been used as the basis of a common antioxidant assay. In DPPH radical scavenging activity(Fig. 1A), L. japonica scavenged DPPH radical by $9.8 \%$ at $12.5 \mu \mathrm{g} / \mathrm{ml}, 24.8 \%$ at $25 \mu \mathrm{g} / \mathrm{ml}, 34.3 \%$ at $50 \mu \mathrm{g} / \mathrm{ml}, 61.1 \%$ at $100 \mu \mathrm{g} / \mathrm{ml}$ and $75.8 \%$ at $200 \mu \mathrm{g} / \mathrm{ml}$, respectively. In addition, $C$. morifolium and $M$. arvensis removed DPPH radical by $15.6 \%$ and $10.4 \%$ at $12.5 \mathrm{\mu g} / \mathrm{ml}, 34.8 \%$ and $22.8 \%$ at $25 \mu \mathrm{g} / \mathrm{ml}, 66.9 \%$ and $43.3 \%$ at $50 \mu \mathrm{g} / \mathrm{ml}, 87.4 \%$ and $69.1 \%$ at $100 \mu \mathrm{g} / \mathrm{ml}$, and $92.1 \%$ and $73.2 \%$ at 200 $\mu \mathrm{g} / \mathrm{ml}$, respectively. However, $\mathrm{P}$. rhizoma did not affect DPPH radical scavenging. In $\mathrm{Fe}^{2+}$ chelating activity, the chelating activity was highest in $L$. japonica while lowest in $\mathrm{P}$. rhizoma among the herbal teas.

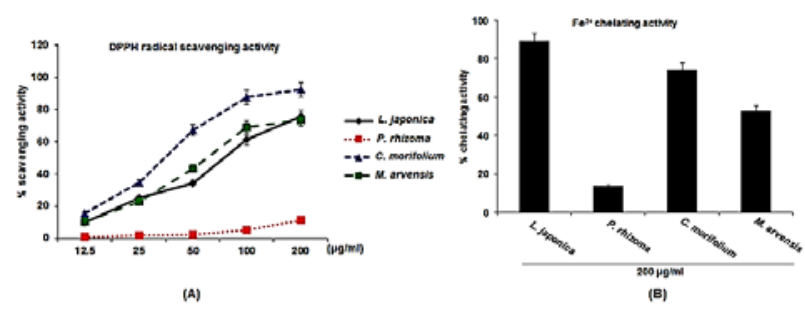

Fig. 1. DPPH radical scavenging activity and $\mathrm{Fe}^{2+}$ chelating activity of the herbal teas. The absorbance values were converted to scavenging activity or chelating activity (\%). 


\section{Protective effect of the herbal teas} against oxidative DNA damage

The inhibitory effect of the extracts from the herbal teas was evaluated using invitro fenton reaction between $\mathrm{H}_{2} \mathrm{O}_{2}$ and $\mathrm{Fe}^{2+}$. Undamaged plasmid DNA was mainly the supercoiled form (SC) in absence of $\mathrm{H}_{2} \mathrm{O}_{2}$ and $\mathrm{Fe}^{2+}$ (Fig. 2, lane 1). When the oxidative damage of plasmid DNA was induced by $\mathrm{H}_{2} \mathrm{O}_{2}$ and $\mathrm{Fe}^{2+}$, $\mathrm{SC}$ was converted into the open-circular form (OC)(Fig. 2, lane 2). The extracts from $L$. japonica, $M$. arvensis and $C$. morifolium attenuated the conversion of $\mathrm{SC}$ into OC, which indicates $L$. japonica, $M$. arvensis and $C$. morifolium could protect DNA from oxidative damage. However, the extracts from P. rhizoma did not affect the protection of oxidative DNA damage.

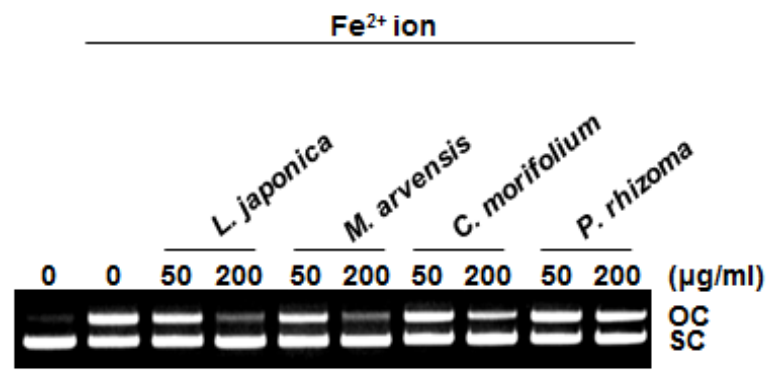

Fig. 2. Protective effect of the herbal teas against oxidative DNA damage. Oxidative damage of $\varphi \mathrm{X}-174 \mathrm{RF}$ I plasmid DNA was induced by $\mathrm{FeSO}_{4}$. SC and $\mathrm{OC}$ mean supercoiled and open-circular form, respectively.

\section{Effect of the herbal teas on nitric oxide} (NO) production in LPS-stimulated RAW264.7 cells

Since ROS is associated with inflammation, we also evaluated the effect of the herbal teas on NO production in LPS-stimulated RAW264.7 cells. RAW264.7 cells were pretreated with the extracts from the herbal teas for $2 \mathrm{~h}$ and then co-treated with LPS (1 $\mu \mathrm{g} / \mathrm{ml}$ ) for the additional $18 \mathrm{~h}$. As shown in Fig. 3, treatment of LPS without the extracts induced NO overproduction in LPS-stimulated RAW264.7 cells, while pretreatment of the extracts from $C$. morifolium suppressed LPS-mediated NO overproduction. However, the extracts from $L$. japonica, $M$. arvensis and $\mathrm{P}$. rhizoma did not affect NO production in LPS-stimulated RAW264.7 cells.

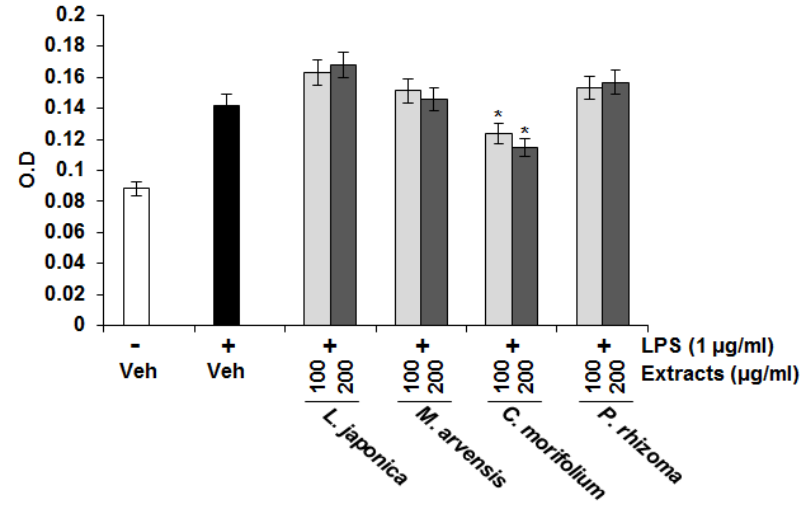

Fig. 3. Effect of the extracts from the herbal teas on LPS-induced NO production in RAW264.7 cells. Cells were pre-treated with the extracts from the herbal teas for $2 \mathrm{~h}$ and then co-treated with 1 $\mu \mathrm{g} / \mathrm{ml}$ of LPS for $15 \mathrm{~h}$. The NO concentration in the medium was measured using Griess reagent. ${ }^{*} p<0.05$ compared to LPS-stimulated cells.

\section{Inhibitory effect of the extracts from $C$.}

\section{morifolium on LPS-induced $\mathrm{NF}-\kappa \mathrm{B}$ activation}

\section{in RAW264.7 cells}

To elucidate the effect of the extracts from $C$. morifolium on $\mathrm{NF}-\kappa \mathrm{B}$ activation by LPS, we carried out Western blot for $\mathrm{I} \kappa \mathrm{B}-\alpha$ degradation in LPS-stimulated RAW264.7 cells. As shown in Fig. 4A, LPS induced I $\kappa \mathrm{B}-\alpha$ degradation at $15 \mathrm{~min}$ after the stimulation. However, pretreatment of the extracts from $C$. morifolium dose-dependently attenuated $\mathrm{I} \kappa \mathrm{B}-\alpha$ degradation. $\mathrm{NF}-\kappa \mathrm{B}$ p65 nuclear translocation resulted from $\mathrm{I} \kappa \mathrm{B}-\alpha$ degradation is essential for $\mathrm{NF}-\kappa \mathrm{B}$ activation. Thus, we tested if the extracts from $C$. morifolium block p65 nuclear translocation. As shown in Fig. 4B, LPS markedly increased an amount of p65 in nuclear of RAW264.7 cells, while the extracts from $C$. morifolium inhibited LPS-induced p65 nuclear translocation in RAW264.7 cells. Translocated p65 into nucleus directly binds to the $\mathrm{NF}-\kappa \mathrm{B}$ binding site and subsequently induces transcriptional activation of $\mathrm{NF}-\kappa \mathrm{B}$. So, we determined whether the extracts from $C$. morifolium inhibit transcriptional activity of $\mathrm{NF}-\kappa \mathrm{B}$ using $\mathrm{pNF}-\kappa$ B-Luc-cis-reporter plasmid. In this assay, the extracts from $C$. morifolium inhibited LPS-induced transcriptional activity of $\mathrm{NF}-\kappa \mathrm{B}$ in RAW264.7 cells (Fig. 4C). Overall, the results indicated that the extracts from $C$. morifolium may inhibit $\mathrm{NF}-\kappa \mathrm{B}$ activation by suppression of p65 translocation into the nucleus via blocking the $\mathrm{I} \kappa \mathrm{B}-\alpha$ degradation. 
(A)

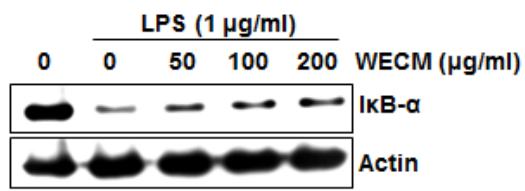

(B)

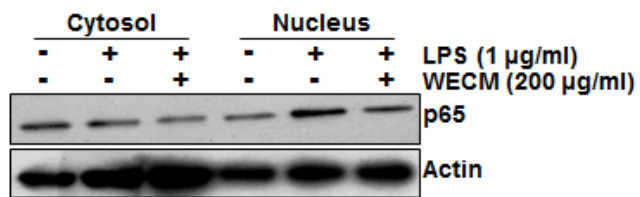

(C)

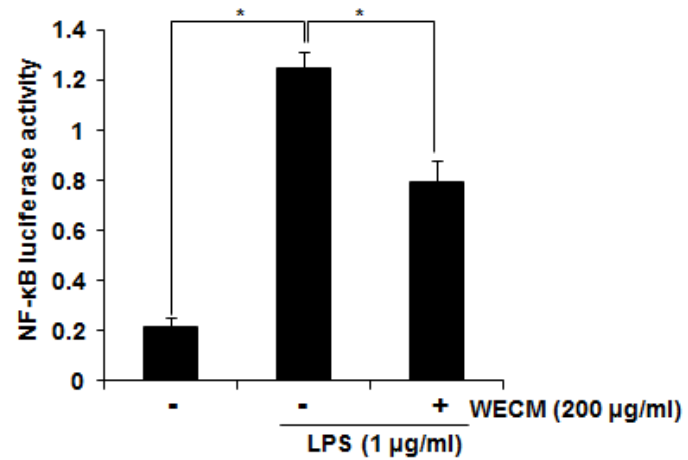

Fig. 4. Effect of the extracts from C. morifolium on $\mathrm{NF}-\kappa \mathrm{B}$ activation in LPS-stimulated RAW264.7 cells. RAW264.7 cells were pre-treated with indicated concentrations of the extracts from $C$. morifolium for $2 \mathrm{~h}$, and then co-treated with LPS $(1 \mathrm{\mu g} / \mathrm{ml})$ for an additional $15 \mathrm{~min}(\mathrm{~A})$ or $30 \mathrm{~min}(\mathrm{~B})$. Cell lysate $(30 \mu \mathrm{g})$ were resolved by $12 \%$ SDS-PAGE, transferred to nitrocellulose membranes, and probed with antibodies against $\mid \kappa \mathrm{B}-\alpha$ and $\mathrm{p} 65$. The proteins were then visualized using ECL detection. Actin was used as an internal control. For $\mathrm{NF}-\kappa \mathrm{B}$ luciferase activity (C), pNF- $\kappa \mathrm{B}-\mathrm{Luc}$ plasmid-transfected cells were pre-treated with the extracts from C. morifolium for $2 \mathrm{~h}$, and then co-treated with LPS $(1 \mu \mathrm{g} / \mathrm{ml})$ for an additional $15 \mathrm{~h}$. The cells were harvested in $1 \times$ luciferase lysis buffer, and luciferase activity was measured using a dual-luciferase assay kit. WECM means the water extracts from $C$. morifolium. Values given are the mean $\pm S D(n=3) .{ }^{*} p<0.05$ compared to LPS-stimulated cells.

\section{Discussion}

Oxidative stress induced by an imbalance between production of reactive oxygen species (ROS) and antioxidants have been associated with pathogenic processes including carcinogenesis and inflammation ${ }^{6,15)}$. This imbalance induces the damage of important biomolecules such as DNA, protein and lipids, which results in somatic mutations and neoplastic transformation $1^{6-18)}$. In addition, ROS induces chronic inflammation by stimulating the production of nitric oxide (NO). Thus ROS has been regarded as important mediators of inflammatory processes and consequently, their neutralization by antioxidants and radical scavengers can attenuate inflammation ${ }^{7)}$.

Radical scavenging activity is very important owing to the deleterious role of free radicals in biological systems and generally proceeds via hydrogen atom transfer or donation of electrons ${ }^{19)}$. To evaluate free radical scavenging activity of the extracts from herbal tea, we used DPPH radical. DPPH radical scavenging assays has been used to perform the free radical scavenging activity based on the reduction of these radicals. In this study, we found that the extracts from $L$. japonica, $M$. arvensis and $C$. morifolium dose-dependently scavenged DPPH radical. In addition, we evaluated the $\mathrm{Fe}^{2+}$ chelating activity and found that the extracts from $L$. japonica, $M$. arvensis and $C$. morifolium chelated $\mathrm{Fe}^{2+}$ ion. Anti-oxidant activity can be affected by two factors: (1) scavenging of radicals formed during reactions and (2) inhibiting the radical generation. Therefore, the $\mathrm{Fe}^{2+}$ chelating activity of the extracts from $L$. japonica, $M$. arvensis and $C$. morifolium indicates that these herbal teas can inhibit the generation of hydroxyl radical by fenton reaction between $\mathrm{H}_{2} \mathrm{O}_{2}$ and $\mathrm{Fe}^{2+}$ ion. And these extracts prevented oxidative DNA damage by hydroxyl radical generated from fenton reaction between $\mathrm{H}_{2} \mathrm{O}_{2}$ and $\mathrm{Fe}^{2+}$.

There is growing evidence that ROS can induce chronic inflammation $^{6)}$. NO, one of the major mediators of chronic inflammation is strongly cytotoxicity and tissue damage involved in several processes such as inflammation and immunoregulation ${ }^{20)}$. In this study, the extracts from $C$. morifolium inhibited the overproduction in LPS-stimulated RAW264.7 cells. This result indicates that $C$. morifolium has anti-inflammatory effect in mouse macrophage.

$\mathrm{NO}$ is regulated by $\mathrm{NF}-\kappa \mathrm{B}$ signaling pathway. NF$\kappa \mathrm{B}$ is a transcription factor formed by $\mathrm{p} 50$ and $\mathrm{p} 65$. In absence of stimuli, $\mathrm{NF}-\kappa \mathrm{B}$ activity is suppressed in the cytoplasm by forming a complex with an inhibitory $\mathrm{I} \kappa \mathrm{B}$ protein. The external stimuli such as LPS or $\mathrm{TNF}-\alpha$ activate the $\mathrm{I} \kappa \mathrm{B}-\alpha$ kinase (IKK), resulting in the phosphorylation of $\mathrm{I} \kappa \mathrm{B}-\alpha$. Phosphorylated $\mathrm{I} \kappa \mathrm{B}-\alpha$ is then ubiquitinated and subsequently degraded by the 26S proteasome, which thereby releases $\mathrm{NF}-\kappa \mathrm{B}$ from the cytoplasmic $\mathrm{NF}-\kappa \mathrm{B}-\mathrm{I} \kappa \mathrm{B} \alpha$ complex and allows $\mathrm{NF}-$ $\kappa \mathrm{B}$ to translocate to the nucleus. Translocated $\mathrm{NF}-\kappa \mathrm{B}$ activates target genes associated with inflammation such as NO. Thus, $\mathrm{NF}-\kappa \mathrm{B}$ has been shown to be the most influencing transcription factor inducing inflammatory response and a promising target for anti-inflammatory therapies ${ }^{21,22)}$. In this study, we demonstrated that the extracts from $C$. morifolium inhibit $\mathrm{NF}-\kappa \mathrm{B}$ activation through blocking the nuclear translocation of $\mathrm{NF}-\kappa \mathrm{B}$ p65 via suppressing $\mathrm{I} \kappa \mathrm{B}-\alpha$ degradation.

\section{Conclusion}

In this study for evaluating antioxidant and anti-inflammatory effect of herbal teas, the results 
were below:

1. The extracts from $L$. japonica, $M$. arvensis and $C$. morifolium scavenged DPPH radical and chelated $\mathrm{Fe}^{2+}$ ion.

2. The extracts from $L$. japonica, $M$. arvensis and $C$. morifolium protected DNA from oxidative damage induced by hydroxyl radical.

3. The extracts from $C$. morifolium inhibited $\mathrm{NO}$ production in LPS-stimulated RAW264.7 cells.

4. The extracts from $C$. morifolium inhibited $\mathrm{NF}-\kappa \mathrm{B}$ activation through attenuating p65 nuclear translocation via blocking $\mathrm{I} \kappa \mathrm{B}-\alpha$ degradation in LPS-stimulated RAW264.7 cells

Together, this study indicates that $L$. japonica, $M$. arvensis and $C$. morifolium possess the protective effect against the oxidative DNA damageand $C$. morifolium also exerts anti-inflammatory effect.

\section{Acknowledgement}

This study was supported by the BK21 PLUS program of Ministry of Education.

\section{References}

1. Barnham KJ, Masters CL, Bush AI. Neurodegenerative diseases and oxidative stress. Nat Rev. 2004 ; 3 : 205-14.

2. Yanai N, Shiotani S, Hagiwara S, Nabetani H, Nakajima M. Antioxidant combination inhibits reactive oxygen species mediated damage. Biosci Biotechnol Biochem. $2008 ; 72: 3100-6$.

3. Young IS, Woodside JV. Antioxidants in health and disease. J Clin Pathol. 2001 ; 54 : 176-86.

4. Huang D, Ou B, Prior RL. The chemistry behind antioxidant capacity assays. J Agri Food Chem. $2005 ; 53: 1841-56$.

5. Chan EWC, Lim YY, Chong KL, Tan JBL, Wong SK. Antioxidant properties of tropical and temperate herbal teas. J Food Compos Anal. 2010 ; 23 : 185-9.

6. Naik E, Dixit VM. Mitochondrial reactive oxygen species drive proinflammatory cytokine production. J Exp Med. 2011 ; 208 : 417-20.

7. Geronikaki AA, Gavalas AM. Antioxidants and anti-inflammatory diseases: synthetic and natural antioxidants with anti-inflammatory activity. Com
Chem High T Scr 2006 ; 9 : 425-42.

8. Mukhtar H, Ahmad N. Tea polyphenols: prevention of cancer and optimizing health. Am J Clin Nutr. $2000 ; 71: 1698-702$.

9. Aoshima H, Hirata S, Ayabe S. Antioxidative and anti-hydrogen peroxide activities of various herbal teas. Food Chem. 2007 ; 103 : 617-22.

10. Tsai PJ, Tasai TH, Yu CH, Ho SC. Comparison of $\mathrm{NO}$-scavenging and $\mathrm{NO}$-suppressing activities of different herbal teas with those of green tea. Food Chem. 2007 ; 103 : 181-7.

11. Craig WJ. Health-promoting properties of common herbs. Am J Clin Nutr. 1999 ; 70 : 491-9.

12. Si W, Gong J, Tsao R, Kalab M, Yang R, Yin Y. Bioassay-guided purification and identification of antimicrobial components in Chinese green tea extract. J Chromatogr A. 2006 ; 1125 : 204-10.

13. Hus B, Coupar IM, Ng K. Antioxidant activity of hot water extract from the fruit of the Doum palm, Hyphaene thebaica. Food Chem. 2006 ; 98 : 317-28.

14. Jung Y, Surh Y. Oxidative DNA damage and cytotoxicity induced by copper-stimulated redox cycling of salsolinol, a neurotoxic tetrahydroisoquinoline alkaloid. Free Radical Biol Med. 2001 ; 30 : 1407-17.

15. Kong AN, Yu R, Hebbar V, Chen C, Owuor E, Hu R, Ee R, Mandlekar S. Signal transduction events elicited by cancer prevention compounds. Mutat Res. 2001 ; 480-481 : 231-41.

16. Durackova Z. Some current insights into oxidative stress. Physiol Res. 2010 ; 59 : 459-69.

17. Fang J, Seki T, Maeda H. Therapeutic strategies by modulating oxygen stress in cancer and inflammation. Adv Drug Deliv Rev. 2009 ; 61 : 290-302.

18. Khandrika L, Kumar B, Koul S, Maroni P, Koul HK. Oxidative stress in prostate cancer. Cancer Lett. 2009 ; 282 : 125-36.

19. Niki E, Noguchi N. Evaluation of antioxidant capacity. What capacity is being measured by which method? IUBMB Life. 2000 ; 50 : 323-9

20. Reddy BD, Reddanna P. Chebulagic acid (CA) attenuates LPS-induced inflammation by suppressing $\mathrm{NF}-\mathrm{\kappa B}$ and MAPK activation in RAW 264.7 macrophages. Biochem Biophys Res Commun. 2009 ; 381 : 112-7.

21. Mankan AK, Lawless MW, Gray SG, Kelleher D, McManus R. NF-kappaB regulation: the nuclear response. J Cell Mol Med. 2009 ; 13 : 631-43.

22. Sarkar FH, Li Y, Wang Z, Kong D. NF-kappaB signaling pathway and its therapeutic implications in human diseases. Int Rev Immunol. 2008 ; 27 : 293-319. 